\title{
Some Physicochemical Properties of the Whole Fruit Mandarin Jam
}

\author{
Salih Aksay*, Habip Tokbaş, Rıdvan Arslan, Fırat Çınar
}

${ }^{I}$ Department of Food Engineering, Mersin University, 33343 Mersin, Turkey

A R T I C LE IN F O

\section{Research Article}

Received 04 April 2018

Accepted 10 April 2018

\section{Keywords.}

Mandarin

Satsuma

Jam

Citrus unshiu March

Physicochemical properties

\begin{tabular}{l}
\hline Corresponding Author: \\
\hline E-mail: saksay@mersin.edu.tr
\end{tabular}

\begin{abstract}
A B S T R A C T
The citrus fruits have a high nutritive value and are also beneficial effects for human health due to their high flavonoid content. Mandarin (Citrus unshiu March.) a kind of citrus fruits are consumed as fresh and processed juice and/or juice concentrate. The aim of this work was to produce jam and evaluate its physical, chemical and sensory qualities from satsuma mandarins that are inconsumable or low quality small fruits. The jam was produced with 1:1 fruits: sugar ratios in an open vessel by traditional technique. Produced whole fruit mandarin jam had reasonable favour score from applied hedonic scale. The mean values of total soluble solid, titratable acidity as citric acid, dry matter, ash percent and $\mathrm{pH}$ of jam samples on wet basis were found as 70.38, 0.098, 74.77, 0.28 and 2.87 respectively. Hunter L, a and b values of tangerin jam were measured as 45.34, 11.48, and 21.16 respectively. Total phenolic content, antioxidant capacity and vitamine $\mathrm{C}$ of sample were measured $201,60 \mathrm{mg} / 100 \mathrm{~g}$ as gallic acid equivalent and $102.24 \mathrm{mg}$ $\mathrm{FeSO}_{4} .7 \mathrm{H}_{2} \mathrm{O} / 100 \mathrm{~g}, 0.07 \mathrm{mg} / 100 \mathrm{~g}$ respectively.
\end{abstract}

DOI: https://doi.org/10.24925/turjaf.v6i5.632-635.1948

\section{Introduction}

Citrus genus belongs to the Rutaceae family and it is divided into two genera that is Papeda and Eucitrus that includes Citrus unshiu March. satsuma mandarin. The name mandarin has been used synonymously with tangerine. Satsuma mandarin which is used in this work is a citrus subgenera designated as citrus reticulate. Among the various types of mandarin (citrus reticulate) the most common grown and exported species in the world are Satsuma, Clementine, Mineola and Fortuna (Kaygisiz and Aybak, 2005; Del Caro et al., 2004).

Citrus fruits are recognized as an important part of the human diet because of having biologically active compounds. Lots of epidemiological studies have demonstrated that there is a significant corelation between fruit and vegetable consumption and low risk of degenerative diseases, such as cancer, diabetes, cardiovascular and neurological disease (Ibrahim and Gad, 2015; Igual et al., 2010). Because the citrus fruits possess a high level of antioxidant properties which are closely linked to the phenolic compounds (Ma et al., 2008; Perez-Lopez, 2010). Previous investigations have proved that citrus fruits are a good source of polyphenols. The health promoting effects have been associated with high level of polyphenols. Besides vitamin $\mathrm{C}$ and carotenoid this genus contains phenolic compounds including flavonoids (narirutin, hesperidin, naringin and neohesperidin) and phenolic acids (benzoic acid and hydroxycinnamic acids). These compounds are assumed potential health promoting agents (Igual et al., 2010; Perez-Lopez et al., 2011; Sdiri et al., 2012). Phenolic compounds have been found to possess antiallergenic, antiartherogenic, antiinflammatory, antimicrobial, antioxidant, antithrombotic, cardioprotective and vasodilatory effects. The nutritional and promoting effects have been attributed to their antioxidant activity and free radical scavenging abilities (Perez-Lopez et al., 2011).

Mostly, most of cirtus fruits harvested in Turkey are consumed as fresh fruit in the domestic market. But in the other countries these fruits are not only consumed fresh but also used for canning, juice and jam processing (Ibrahim and Gad, 2015; Ye et al., 2011; Yu et al., 2007). Canned slice and juice from mandarin are elaborated items in Spain (Perez-Lopez, 2010). Remarkable percentages of canned mandarin fruits are exported mainly to USA, Japan and EU, etc. (Ibrahim and Gad, 2015).

Turkey is the fourth major worldwide producer of mandarin (858.000 tons in 2010) behind China $(10,1$ million tons), Spain (1,7 million tons) and Brazil (1,1 million tons) in 2010. Citrus is the most important fruit plant in Turkey with $19 \%$ of the harvested fruits. Mandarin production is about $30.4 \%$ of total citrus production with 942000 tons per 38692 hectares in Turkey and mainly produced in Mediterranean and 
Aegean region. Most of mandarin production is in Adana (28\%), Hatay (25\%) and Mersin (18\%). Satsuma that is also known as Rize Mandarin is the most prefered variety of cultivated mandarin and about 106620 tons have been produced per 30038 decares in Mersin according to TUIK data in 2012 and 2015 (Anonymous $^{\mathrm{a}}$, 2015; Anonymous ${ }^{\mathrm{b}}$ 2017; Anonymous ${ }^{\mathrm{c}}$, 2012; Anonymous ${ }^{\mathrm{d}}$, 2012).

Jam is a preservation technique which is an early process to preserve fruit for consumption the during offseason. Preparation of jam is prepared by mixing fruit, sugar, pectin, acid and other ingredients such as preservatives, colouring and flavouring agents. Then this mixture is boiled until obtaining suitable gelled consistency (Touati et al., 2014). Since low cost, long availability for all year and organoleptic properties jam is one of the most popular product (Mohd Naeem et al., 2017).

In recent years, innovation in the agri-food sector has been increased because of changes living standard and demand concerning the nutritional, healthy and safe food products. About $65 \%$ of total production of citrus fruits is destined to the fresh consumption whereas the $35 \%$ remaining is used for in the industrial processing (Pretel et al., 2008). In view of this circumstance it is quite interesting to improve new product as distinct from existing products such as can and juice.

In this work, potential of whole fruit jam production from over-mature and undersize inadequate quality citrus packaging wastes. Physicochemical (colour, pH, acidity, total soluble solid, dry matter, ash percent), nutritional (total phenolic content, antioxidant capacity and vitamin C) and sensorial properties of whole fruit mandarin jam were evaluated.

\section{Material and Methods}

Satsuma mandarin for jam processing were harvested at the fully ripe stage from a commercial farm in Mersin, Turkey in December 2016. Fruits were sorted by maturity, shape and colour after harvesting and $3-4 \mathrm{~cm}$ in diameter fruits free from defects were used to produce whole fruit jam. Mandarins were stored at $4^{\circ} \mathrm{C}$ until analysis and jam is produced in a week after harvesting.

Jam production was performed in laboratory conditions, under atmospheric pressure, according to traditional procedure. First fruits were washed with water before processing. Formulation of jam was prepared with 1:1 fruits:sugar ratios. Then fruits with sugar were mixed in an open vessel and was boiled. During the boiling total soluble solids (TSS) of mass was measured by a refractometer and the final TSS of mixture reached to 70 ${ }^{\circ} \mathrm{Bx}$, the obtained jam was cooled down to approximately $80^{\circ} \mathrm{C}$ and was hot filled into glass jar and then immediately was sealed with twist off caps. Samples were stored without direct exposure to sunlight at room temperature before analysis.

Before extraction and analysis, jam and fruit samples were homogenized in a blender and analytical determinations were carried out on homogenised samples. Mandarin fruits and jam samples were analysed according to the methods described by Cemeroglu (2010) to determine the following properties: vitamin $\mathrm{C}, \mathrm{pH}$, Titratable acidity (TA) as citric acid, total soluble solid
(TSS) in brix $\left({ }^{\circ} \mathrm{Bx}\right)$, dry matter percent (DM) and ash percent. Color of jam samples were measured by a Hunter Lab color meter (ColorQuest XE, HunterLab, made in U.S.A.) calibrated with a standart white and light plate and expressed as $\mathrm{L}^{*}, \mathrm{a}^{*}$ and $\mathrm{b}^{*}$ values.

The samples of jam and fruit taken randomly were extracted with acidified methanol (80\%) solvent. In 100 $\mathrm{mL}$ of acidified methanol 2 grams of sample was extracted for 2 hours at room temperature. All extractions were done at 1/50 (w/v) fruits:solvent ratio.

The ferric reducing antioxidant power test was conducted according to Benzie and Strain (1996). Acetate buffer (0.3M, pH 3.6) was prepared by dissolving $40.8 \mathrm{~g}$ $\mathrm{C} 2 \mathrm{H} 3 \mathrm{O} 2 \mathrm{Na} .3 \mathrm{H}_{2} \mathrm{O}$ in $1 \mathrm{~L}$ of distilled water and $\mathrm{pH}$ adjusted to 3.6 by galaciel acetic acid. 23.4 milligram TPTZ (2,4,6-tripyridyl-S-triazine) was dissolved in 7.5 $\mathrm{mL} \mathrm{HCl}(40 \mathrm{mM})$ for preparing Triazine solution. $20 \mathrm{mM}$ ferric solution was prepared by using $\mathrm{FeCl}_{3} \cdot 6 \mathrm{H}_{2} \mathrm{O}$ in water. Acetate buffer, Triazine and ferric solution with a ratio of 10:1:1 was mixed for obtain FRAP reagent and warmed to $37^{\circ} \mathrm{C}$ in water bath. $200 \mu \mathrm{L}$ of methanolic extract of sample was added to $1.8 \mathrm{~mL}$ of FRAP reagent and mixed before incubation at $37^{\circ} \mathrm{C}$ for 10 miutes. At the end of 10 minute incubation absorbance of reaxtion mixture at $593 \mathrm{~nm}$ was measured by spectrophotometer (Cary 60 UV-Vis, Agilent Technologies, Malaysia). For the standart calibration curve solutions of $\mathrm{FeSO}_{4} .7 \mathrm{H}_{2} \mathrm{O}(0$ $100 \mathrm{ppm}$ ) were used and the results were expressed as $\mathrm{mg} / 100 \mathrm{geSO}_{4} .7 \mathrm{H} 2 \mathrm{O}$.

Total phenolic content was measured according to Velioglu et al. (1998) the by spectrophotometer based on a colorimetric oxidation/reduction reaction. FolinCiocalteu reagent was used as a oxidizing agent. To 0.2 $\mathrm{ml}$ of extract, $1.5 \mathrm{ml}$ of Folin-Ciocalteu reagent (diluted 10 times with water) was added. After $5 \mathrm{~min}, 1.5 \mathrm{ml}$ of $\mathrm{Na}_{2} \mathrm{CO}_{3}(60 \mathrm{~g} / \mathrm{L})$ were added. The sample was incubated for $90 \mathrm{~min}$ at room temperature. After incubation period the absorbance was read at $725 \mathrm{~nm}$ against a blank. For a control sample, $0.2 \mathrm{ml}$ of solvents were used. Quantitative measurements were performed, based on a standard calibration curve of gallic acid in acified methanol. The mean results of analyses were expressed as $\mathrm{mg} / 100 \mathrm{~g}$ of gallic acid equivalents (GAE).

Scoring test was used to determine the quality and acceptibility of jam samples by 10 panelists with sensorial properties of appearance, colour, flavour, texture and acceptability. The individual products were scored for the intensity of each sensory parameter. The panelists were requested to use a scale ranging from 1 to 9 to ascertain the intensity of each parameter tested, where 1: undesirable, 5: moderate intensity and 9: extremely intensive/favorible.

\section{Results and Discussion}

This is the first experimental study about production from whole fruit mandarin. No information was found in the literature regarding the whole fruit mandarin jam or mandarin jam processing and also quality attributes. The results of the chemical analysis of the fruit and jam samples were shown in the Table 1 as mean values. These parameters are important factors to evaluate the quality of citrus cultivars and citrus-based products. 
Table 1 Physicochemical and sensorial properties of mandarin and whole fruit mandarin jam

\begin{tabular}{|c|c|c|}
\hline Physicochemical properties & Fruit & Jam \\
\hline r & 2.65 & 2.87 \\
\hline Total soluble solid $\left({ }^{\circ} \mathrm{Bx}\right)$ & 11.5 & $70-74.7$ \\
\hline Titratable acidity (as citric acid \%) & 0.88 & 0.098 \\
\hline Dry matter $(\%)$ & 16.87 & 70.38 \\
\hline Ash $(\%)$ & 3.67 & 0.28 \\
\hline Vitamin C & $0.11 \mathrm{mg} / 100 \mathrm{~g}$ fruit & $0.07 \mathrm{mg} / 100 \mathrm{~g}$ jam \\
\hline $\mathrm{L}^{*}$ value & 56.16 & 45.34 \\
\hline$a^{*}$ value & 36.45 & 11.48 \\
\hline$b^{*}$ value & 31.05 & 21.16 \\
\hline Total phenolic content (GAE) & $242.25 \mathrm{mg} / 100 \mathrm{~g}$ fruit & $201.60 \mathrm{mg} / 100 \mathrm{~g}$ jam \\
\hline Antioxidant capacity (FRAP) & $164.87 \mathrm{mg} / 100 \mathrm{~g}$ fruit & $102.24 \mathrm{mg} / 100 \mathrm{~g}$ jam \\
\hline \multirow{5}{*}{ Sensorial properties } & \multirow{5}{*}{ - } & Appearance $: 8.0$ \\
\hline & & Colour \\
\hline & & Flavour \\
\hline & & Texture \\
\hline & & Acceptability \\
\hline
\end{tabular}

Mean values of $\mathrm{pH}$ of mandarin and jam samples were seen in Table 1 as 2.65 and 2.87 respectively. The $\mathrm{pH}$ value is significant indicator for jam production which could help obtain suitable gelled consistency. In the Turkish Food Codex it was indicated that $\mathrm{pH}$ value for extra traditional jam must be between 2.8 and 3.5 (Anonymous ${ }^{\mathrm{e}}, 2007$ ). It was observed that the $\mathrm{pH}$ value for mandarin in this study was lower than those obtained by Del Caro et al. (2004), Marti et al. (2011), Harrison et al. (2013). The low pH will contribute to high stability in the formulated jam. The $\mathrm{pH}$ value of jam obtained in our study is lower than those obtained by other author (Yu et al., 2007) which those were ranged from 3.10 to 3.28 . The differences of $\mathrm{pH}$ values for mandarin fruit might be due to variety, climatic conditions, genetic and physiological factors. According to Rababah et al., (2012 $)$ the decrease of $\mathrm{pH}$ value during production might be closely related to an increasing amount of hydroxymethoxyfurfural. Rababah et al., $\left(2012^{\mathrm{b}}\right)$ reported that the reduction of $\mathrm{pH}$ after processing cold be due to an increasing amount of HMF in jams compared whit their fruits.

Jam samples' mean ${ }^{\circ} \mathrm{Bx}$ value 74.7 ) whereas fruit sample had lowest value of $11.5{ }^{\circ} \mathrm{Bx}$. High ${ }^{\circ} \mathrm{Bx}$ value reduces the water activity of food and food is become safer for microbial and some of biochemical deteriorations. The increase in ${ }^{\circ} \mathrm{Bx}$ for jam sample can be due to adding sugar and water loss by boiling process. Similar observations were recorded for some fruits in previous studies. Aslanova et al., (2010) reported that apricot jam had $70.55 \%$ total soluble solids. According to TFC traditional and extra traditional jam must contain $\geq$ $68 \%$ soluble solids. The value of $\mathrm{Bx}$ in this study is agreement with those reported by Tokbas (2009), on black mulberry; Üstün and Tosun (1998), on cherry, strawberry, apricot and rose jam. The data in Table 1 shows that the TA value of fruit achieved higher value $(0.88 \%)$, while jam had lower value (0.098). The measured vitamin $C$ content of fruit was $0.11 \mathrm{mg} / 100 \mathrm{~g}$ whereas of jam was $0.07 \mathrm{mg} / 100 \mathrm{~g}$. High heat treatment into traditional process can be causes of degradation in vitamin C. Similarly, Mohd-Naeem et al. (2017), reported that the differences in vitamin $\mathrm{C}$ content between fruit and jam might be linked to destructive nature of jam making process. Processing of fruit into jam was revealed to be most damaging towards vitamin $\mathrm{C}$ which explains low vitamin $\mathrm{C}$ value in jam sample in this study. In our study ashes were found for fruit and jam as $3.67 \%$ and $0.28 \%$ respectively which are comparable to that of grape, apricot, blueberry and strawberry jams $0.18,0.25,0.12$ and $0.23 \mathrm{~g} / 100 \mathrm{~g}$ respectively (Mohd Naeem et al., 2017).

One of the most important parameters to which consumers choise of foods is colour. The external appearance of product particularly arising from colour is of prime importance (Perez-Lopez, 2010). It was noticed that in this research, colour parameters underwent significant reduction in values. Jam showed significantly lower $\mathrm{L}^{*}, \mathrm{a}^{*}$ and $\mathrm{b}^{*}$ values than fresh fruit. The changing in colour values are assumed by as a result of thermal degradation during heat treatment, illumination, oxygen content and storage conditions (Ma et al., 2008; PerezLopez, 2010). The decrease for $\mathrm{L}^{*}$ value into jam was reported by Igual et al. (2010), as a consequence of sugar caramelization which contributes to dark colour. Redness parameter $\left(a^{*}\right)$ values showed that fruit had higher value (36.45) and decreased significantly after jam processing (11.48). These indicate that the jam lost its particular colour, reducing lightness and changing from initial the most redish (highest $a^{*}$ ) value of fruit to yellowish tones for jam. Such a case attributed to the formation of brown pigment by Maillard reaction (Touati et al., 2014). As regards $b^{*}$ values similar decrease were obtained and were remarkable affected by jam processing.

Data in Table 1 show that thermal treatment had significant effect on both total phenolic content and antioxidant capacity in mandarin jam. These results showed that mandarin jam had lower amount of total phenolic content $(201.60 \mathrm{mg} / 100 \mathrm{~g})$ and antioxidant activity $(102,24 \mathrm{mg} / 100 \mathrm{~g})$ than fruit sample. The total phenolic content was highly influenced by process conditions.

Decrease in phenolic content and antioxidant capacity could be result of high temperature heat treatment during boiling process of jam in atmospheric conditions for time to reach desired ${ }^{\circ} \mathrm{Brx}$. These results agree with the findings of other researchers studying the effect of jam processing on phenolic contents and antioxidant capacity 
in different fruits (Rababah et al., 2012 ${ }^{\text {a }}$, Rababah et al., 2011). Despite the reduction in values of total phenolics and antioxidant activity, whole mandarin jam has reasonable amount of phenolic content and antioxidative capacity.

Whole mandarin jam has good acceptability with average 7.6 point and good intensities of appearance (8), colour (7.8), fresh mandarin flavour (8.1), texture (6.6). Thermal treatment caused only a slight decrease in sensory properties of jam product. But in spite of the slight decrease in overall acceptability whole fruit jam could be prefered and consumed easily by many consumers in point of nutritive food product.

\section{Conclusions}

Jam processing could be a way of consumption of mandarin and result of sensory analysis showed that whole fruit mandarin jam was well accepted by panelist because of conserved typical fruit flavour. Besides whole fruit jam has lower small proportions of phenolic content, antioxidnat activity and vitamin $\mathrm{C}$ than fresh fruit because of high temperature heat treatment, it can be suggested that whole fruit mandarin jam can be consumed as desert substitude with some nutritional and sensorial properties.

\section{References}

Anonymousa . 2015. TUIK (Turkish Statistical Institute), Ankara, Turkey.

Anonymous ${ }^{\mathrm{b}}$. Chamber of Agricultural Engineers (http://www.zmo.org.tr/genel/bizden_detay.php?kod=23137). 2017

Anonymous ${ }^{c}$. 2012. TUIK (Turkish Statistical Institute), Ankara, Turkey.

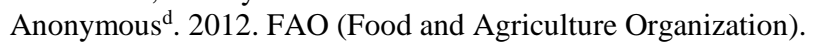

Anonymous ${ }^{\mathrm{e}}$. 2007. Türk Gıda Kodeksi Reçel, Jöle, Marmelat Ve Tatlandırılmış Kestane Püresi Tebliği. 09.03.2007 Tarih ve 26457 Mükerrer Sayılı Resmi Gazete.

Aslanova D, Bakkalbasi E, and Artik N. 2010. Effect of storage on 5- hydroxymethylfurfural (HMF) formation and colour change in jams. International Journal of Food Properties 13:904-912.

Benzie IFF, Strain JJ. 1996. The ferric reducing ability of plasma (FRAP) as a measure of antioxidant power: The FRAP assay. Analytical Biochemistry 239:70-76.

Cemeroglu B. 2010. Gıda Analizleri, 2. Baskı, Gıda Teknolojisi Derneği Yayınları No:34. Ankara. ISBN:978-975-98578-68.

Del Caro A, Piga A, Vacca V, and Agabbio M. 2004. Chanhes of flavonoids, vitamin $\mathrm{C}$ and antioxidant capacity in minimally processed citrus segments and juices during storage. Food Chemistry 87:99-105.

Harrison MR, Spier JD, Coneva ED, Dozier W, Woods, FM. 2013. Orchard design influences fruit quality, canopy temperature, and yield of satsuma mandarin (citrus unshiu 'owari'). International Journal of Fruit Science 13:334-344.

Ibrahim MM, Gad MM. 2015. The relationship between harvest date and storage life of washington navel orange fruits. Middle east journal of applied sciences. 5:1247-1256.

Igual M, Contreras C, Martinez-Navarrete N. 2010. Nonconventional techniques to obtain grapefruit jam. Innovative Food Science and Emerging Technologies, 11:335-341.

Kaygısız H. Aybak HC. 2005. Narenciye yetiştiriciliği. Hasad Yayınc1lik. ISBN: 978-975-8377-05-3.
Ma YQ, Ye XQ, Fang ZX, Chen JC, Xu GH, Liu, DH. 2008. Phenolic compounds and antioxidant activity of extracts from ultrasonic treatment of satsuma mandarin (citrus unshiu Marc.) peels. Jornal of Agricuktural and Food Chemistry 56:5682-5690.

Marti N, Saura D, Fuentes E, Lizama V, Garcia E, MicoBallester MJ, Lorente J. 2011. Fiber from tangerine juice industry. Indusrtrial Crops and Products 33:94-98.

Mohd Naeem MN, Mohd Fairulnizal MN, Norhayati MK, Zaiton A, Norliza AH, Wan Syuriahti WZ, Mohd Azerulazree J, Aswir AR, Rusidah S. 2017. The nutritional composiiton of fruit jams in the malaysian market. Journal of the Saudi Society of Agricultural Sciences 16: 89-96.

Perez-Lopez AJ. 2010. Quality of canned mandarin as affected by preservation liquid. Ciência e Tecnologia de Alimentos. 30:1105-1113.

Perez-Lopez AJ, Lopez-Nicolas JM, Del Cerro I, BeltranGonzalez F, Carbonell-Barrachina A.A. 2011. Effects of preservation liquid on vitamin $\mathrm{C}$, instrumental color, carotenoids and sensory quality of canned satsuma mandarin, 34:1464-1484.

Pretel MT, Sanchez-bel P, Egea I. Romojaro F. 2008. Enzymatic peeling of citrus fruits: Factors affecting degradation of the Albedo. Tree and forestry science and biotechnology, Special Issue 1, 52-59.

Rababah TM, AL-Mahasneh MA, Kilani I, Yang W, Alhamad MN, Ereifej K, Al-u'datt M. 2011. Effect of jam processing and storage on total phenolics, antioxidant activity, and anthocyanins opf different fruits. Journal of the Science of Food and Agriculture 91:1096-1102.

Rababah TM, Al-u'datt M, Al-Mahasneh M, Yang W, Feng H, Ereifej K, Kilani I, Ishmais, MA, 2012 a. Effect of jam processing and storage on phytochemicals and physiochemical properties of cgerry at different temperatures. Journal of Food Processing and Preservation 38:247-254.

Rababah TM, Al-u'datt M, Almajwal A, Brewer S, Feng H, Almahasneh M, Ereifej K, Yang, W. 2012b. Evaluation of the nutraceutical, physiochemical and sensory properties of raisin jam. Journal of Food Science, 77:609-613.

Sdiri S, Bermejo A, Aleza P, Navarro P, Salvador, A. 2012. Phenolic composition, organic acids, sugars, vitamin $\mathrm{C}$ and antioxidant activity in the juice of two new late-season mandarins. Food Research International 49:462-468.

Tokbas H. 2009. Jam and Marmalade Processing Of Black Mulberry (Morus Nigra L.) And Ant1oxıdant Properties of The Products. Gaziosmanpaşa University, Graduate School of Natural and Applied Science, Department of Food Engineering. Master Thesis. Tokat.p: 127.

Touati N, Tarazona-Diaz MP, Aguayo E, Louaileche, H. 2014. Effect of storage time and temperature on the physicochemical and sensoty characteristics of commercial apricot jam. Food Chemistry, 145:23-27.

Üstün Ş, Tosun İ. 1998. A research study on composition of different types jams. Food, 23:125-131.

Velioglu YS, Mazza G, Gao L, Oomah BD. 1998. Antioxidant activity and total phenolics in selected fruits, vegetables and grain products. Journal of Agricultural Food Chemistry, 46: 4113-4117.

Ye XQ, Chen JC, Liu DH, Jiang P, Shi, J, Xue S, Wu D. 2011. Identification of bioactive composition and antioxidant activity in young mandarin fruits. Food Chemistry 124:1561-1566.

Yu Q, Bi-Jun Z, Yan Z, Hai-Yan Z, Si-Yi P. 2007. Study on aroma components in fruit from three different satsuma mandarin varieties. Agricultural Sciences in China, 6:14871493. 